\title{
Visible Losses to the Mechanical Harvesting of Ratoon Sugarcane Using the Harvester John Deere 3520
}

\author{
Carmen Maria Coimbra Manhães'1, Francisco Maurício Alves Francelino', \\ Rafael Alves de Araújo², Danilo Gomes de Oliveira', Helenilson de Oliveira Francelino², \\ Mirian Peixoto Soares da Silva1, Aline da Silva Santos ${ }^{1}$, Maurício Donato de Moura Júnior \\ ${ }^{1}$ Federal Institute of Education, Science and Technology of Tocantins-FTO, Palmas, Brazil \\ ${ }^{2}$ State University of North Fluminense, Rio de Janeiro, Brazil \\ Email: carmen.manhaes@ifto.edu.br, francisco.francelino@ifto.edu.br, rafael_alvaraujo@yahoo.com.br, \\ danilo.gomes@ifgoiano.edu.br, helenilsonuenf@gmail.com, mirian.silva@ifto.edu.br, aline.santos@ifto.edu.br, \\ mauricio.junior@ifto.edu.br
}

How to cite this paper: Manhães, C.M.C., Francelino, F.M.A., de Araújo, R.A., de Oliveira, D.G., Francelino, H. de O., da Silva, M.P.S., Santos, A. da S. and de Moura Júnior, M.D. (2018) Visible Losses to the Mechanical Harvesting of Ratoon Sugarcane Using the Harvester John Deere 3520. American Journal of Analytical Chemistry, 9, 580-590.

https://doi.org/10.4236/ajac.2018.911042

Received: June 20, 2018

Accepted: November 19, 2018

Published: November 21, 2018

Copyright $(9) 2018$ by authors and Scientific Research Publishing Inc. This work is licensed under the Creative Commons Attribution International License (CC BY 4.0).

http://creativecommons.org/licenses/by/4.0/

\begin{abstract}
The aim of this study was to evaluate the visible loss of sugar cane and the damage to the knuckles, using the John Deere 3520 harvester on three different travel speeds $\left(3.0 ; 4.0\right.$ and $\left.5.0 \mathrm{~km} \cdot \mathrm{h}^{-1}\right)$, in DIC with five repetitions in Campos dos Goytacazes, Rio de Janeiro/Brazil. Each treatment was composed by six lines of harvested cane stumps, with a length of $290 \mathrm{~m}$ each. In these six lines, the remains of sugar cane left in the field were collected by placing the sampling frame in two central lines every $50 \mathrm{~m}$, and separating $40 \mathrm{~m}$ of edge. The sampling area was surrounded by $2 \mathrm{~m}$ wide and $10 \mathrm{~m}$ long, totaling $20 \mathrm{~m}^{2}$. To calculate the damage to stumps, a visual methodology by [1], was used, which classifies the damage grade, ranging from 1 to 4 . Fifty stumps were assessed randomly for each speed, in a sampling area of $1800 \mathrm{~m}^{2}$. The data were submitted to ANOVA and Tukey test at 5\%, in order to compare the effect of different speeds on the losses and damages. There was no significant difference regarding the loss or damage by comparing the different speeds. Therefore, it is more advantageous to use the speed of $5.0 \mathrm{~km} \cdot \mathrm{h}^{-1}$, harvesting more in less time and causing the same level of damage.
\end{abstract}

\section{Keywords}

Damages, Saccharum spp., Travel Speed, John Deere 3520 Harvester

\section{Introduction}

The sugar cane (Saccharum spp.) is one of the main crops grown in Brazil. Me- 
chanized harvesting of the sugar cane, in the North Fluminense region, has increased considerably in recent years, mainly due to the need for adjustments to state laws. However, this type of harvesting has caused great losses and may also cause damage to the stumps, which considerably reduce the flushing and provide the attack of pests and diseases, reflecting the loss of productivity on the subsequent crop.

Due to that, it is necessary to evaluate the losses and damages to the brass knuckles that minimize correcting operational failures. The mills of sugar and ethanol productions are increasingly seeking innovative mechanization in the cane fields, but, in the interest of controlling costs, the aim is also not to lose the quality and to decrease visible loss of sugar cane in the field. Due to these reasons, evaluations of losses by harvesters of sugar cane have been fundamental to the operation management, so that one can act on the process and make the necessary corrections to reduce its incidence, when certain values are very high [2].

The dislocation speed of the sugar cane harvester is directly influenced by the culture and terrain conditions, thus, due to the machine having a high speed, it increases its operational capacity. This leads to an increase on the losses, by containing greater mass to be processed by the harvester, so the speed should be adjusted according to the characteristics of the field, the size and productivity of the sugar cane field [2].

This article aims to evaluate the visible loss of raw material and damage to brass knuckles, using the John Deere 3520 harvester on three different dislocation speeds $\left(3.0,4.0\right.$ and $\left.5.0 \mathrm{~km} \cdot \mathrm{h}^{-1}\right)$ in DIC with five repetitions in Campos dos Goytacazes, Rio de Janeiro/Brazil.

\section{Material and Methods}

The work was conducted in the city of Campos dos Goytacazes, Rio de Janeiro, in a systematized area for mechanized harvesting of sugar cane. The area belongs to Usina Paraíso. The geographic coordinates are $21^{\circ} 45^{\prime} 22^{\prime \prime S}$ and $41^{\circ} 17^{\prime} 25^{\prime \prime} \mathrm{W}$.

The harvester used in this research was the chopped sugar cane harvester John Deere 3520 (Figure 1).

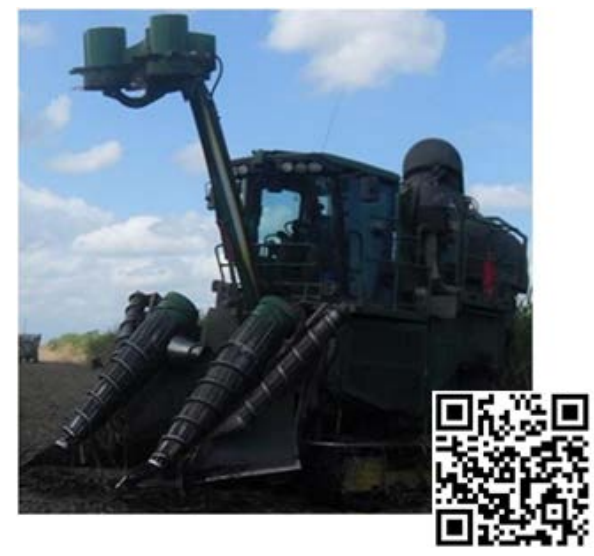

Figure 1. John Deere 3520 Harvester. 
The experiment was composed by three treatments with speeds of 3.0; 4.0 and $5.0 \mathrm{~km} \cdot \mathrm{h}^{-1}$. The design was randomized (DIC), with five repetitions.

The survey of visible loss was conducted in a demarcated area after the harvest, where the remains of sugar cane left in the field, in each treatment, were collected.

The area of each experimental treatment was comprised of six lines of cane stumps harvested with a length of $290 \mathrm{~m}$ each. In these six lines, regarding each speed, leftover sugar canes were collected in the field by placing the sampling frame in two central lines every $50 \mathrm{~m}$, separating $40 \mathrm{~m}$ of edge. The sampling area was surrounded by $2 \mathrm{~m}$ wide and $10 \mathrm{~m}$ long, totaling $20 \mathrm{~m}^{2}$. Five replicates were used, as shown in Figure 2. With the data from the mass loss from each type of the five replicates, the losses $\mathrm{t} \cdot \mathrm{ha}^{-1}$ and percentage of losses were calculated, per treatment.

Visible loss of cane sugar were collected, separated and weighed according to the classification proposed by [1], presented in Table 1 .

The quantitative losses were converted into tons per hectare according to Equation (1).

$$
P=\frac{m}{a} 10
$$

which

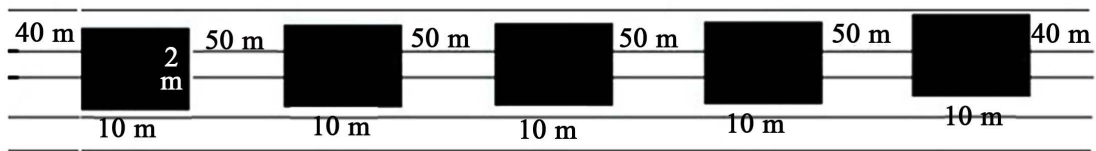

Figure 2. Sampling model of the experiment to compare visible loss of sugar cane in the central rows of each treatment.

Table 1. Description of the types of losses reviewed.

\begin{tabular}{|c|c|}
\hline Peaked grind stone & $\begin{array}{l}\text { Fraction of the stem with the characteristic cut of chipper knife } \\
\text { or the base cutting, on both ends. }\end{array}$ \\
\hline Whole sugar cane & $\begin{array}{l}\text { Sugar fraction with size equal to or higher than } 2 / 3 \text { of the total, } \\
\text { stuck or loose soil by the root length. }\end{array}$ \\
\hline Cane tip & Fraction of stem left on the ground and aggregated to the pointer. \\
\hline Fixed piece & $\begin{array}{l}\text { Middle segment of sugar cane (greater than } 0.2 \mathrm{~m} \text { ), } \\
\text { necessarily attached to the ground. }\end{array}$ \\
\hline Loose piece & $\begin{array}{l}\text { Middle segment of sugar cane (greater than } 0.2 \mathrm{~m} \text { ), } \\
\text { necessarily not attached to the ground. }\end{array}$ \\
\hline Splinter & Segmented fraction of the grinding wheel. \\
\hline Shrapnel & Fragments of torncane. \\
\hline Stump & $\begin{array}{l}\text { Fraction of the stem, cut above the soil surface, } \\
\text { attached to the non-torn roots, with length less than or equal to } 0.2 \mathrm{~m} \text {. }\end{array}$ \\
\hline Total losses & Summation of alllosses \\
\hline
\end{tabular}

Source: [1] 
$P$-quantitativelosses, $\mathrm{t} \cdot \mathrm{ha}^{-1}$;

$m$-mass collected in the area, $\mathrm{kg}$; and

a-samplingarea, $\mathrm{m}^{2}$.

For total losses, the value was calculated in percentage, according to Equation (2).

$$
P \%=\frac{P}{P+\operatorname{prod}} 100
$$

which;

$P \%=$ totallosses\%; and

prod $=$ Productivity of sugarcane fields, $\mathrm{t} \cdot \mathrm{ha}^{-1}$.

To assess the damage caused to the stumps, a visual methodology used by [3] adapted from [4] was used, which quantifies the damage in degrees and is presented in Figure 3. Fifty stumps were analyzed randomly on each treatment.

The results of the mass from each type of loss and damage to the brass knuckles were subjected to the analysis of variance and the treatment averages were compared by Tukey test at $5 \%$ probability, aiming to compare the visible loss between different speeds.

\section{Results and Discussion}

The characteristics of the evaluated sugar cane are rated in Table 2.

The estimated crop yield was higher than the regional average, which average productivity is lower than $50 \mathrm{t} \cdot \mathrm{ha}^{-1}$ [5]. This result may be related to the fact that the first cut of the cane after the sugar plantation renewal and systematization of land for mechanized harvesting with correct spacing of $1.5 \mathrm{~m}$ between rows.

\begin{tabular}{|ccc|c|}
\hline PATING DAMAGE LEVELS INFERIOR LIMIT UPPER LIMIT \\
\hline Without Damage & 1 & 2 & \\
Peripheral Damage & 2 & 3 & \\
Crack & 4 &
\end{tabular}

Figure 3. Methodology for classification of damage to brass knuckles used by [1], adapted from [4].

Table 2. Characteristics of the evaluated sugar cane.

\begin{tabular}{cc}
\hline Characteristics of culture & 74.7 \\
Estimated crop yield $\left(\mathrm{t} \cdot \mathrm{ha}^{-1}\right)$ & 2.4 \\
Average length of culms $(\mathrm{m})$ & 33.0 \\
Average diameter of culms $(\mathrm{mm})$ & \\
\hline
\end{tabular}

Source: author 
Corroborating the estimated productivity encountered by [6] which was of $89 \mathrm{t} \cdot \mathrm{ha}^{-1}$ after the evaluation of the productivity of the systemized area for the mechanized harvesting, also with the first cane cut in the North Fluminense region.

Evaluation of apparent losses in mechanized harvesting of cane sugar has been performed by many researchers, highlighting the studies developed by [6]-[11] which evaluated losses due to the displacement speed.

To minimize visible losses in mechanized harvesting process, it is necessary that the area which will receive the harvester does not have high gaps, has standardized the spacing between lines and length of planted areas and damping control [6].

The differences between the types of losses comparing the different speeds were not significant (Table 3 ).

The data from this study corroborate those found by several authors as [6] who evaluated the influence of three displacement speeds $\left(2.0,3.0\right.$ and $\left.4.5 \mathrm{~km} \cdot \mathrm{h}^{-1}\right)$ of the harvester CASE IH A8800 in Norte Fluminense (North Fluminense), noting that there was no significant difference between the losses at different speeds.

[7] [8] found no significant difference in losses when varying the speed of the harvester.

On the other hand [10], who also evaluated two displacement speeds: 3.2 and $3.6 \mathrm{~km} \cdot \mathrm{h}^{-1}$, of the harvester John Deere 3520 in the state of Mato Grosso found higher values of losses at higher speed.

These results show that the influence, or not, of the speed of the harvester on the quantities of visible losses do not follow a general rule, it always depends on the local conditions of the experiment, the harvester rated, the operator, the synchronism, between the harvester and the transfer, and the speeds applied. Thus not being able to infer that for the same harvester in different conditions results will be the same [6].

Table 3. Comparison of the average types of losses among the different speeds and their respective percentages of total losses in $\mathrm{t} \cdot \mathrm{ha}^{-1}$.

\begin{tabular}{cccc}
\hline Types of losses & Speed 1: & Speed 2: & Speed 3: \\
& $3 \mathrm{~km} \cdot \mathrm{h}^{-1}$ & $4 \mathrm{~km} \cdot \mathrm{h}^{-1}$ & $5 \mathrm{~km} \cdot \mathrm{h}^{-1}$ \\
\hline Peaked Grindstone $\left(\mathrm{t} \cdot \mathrm{ha}^{-1}\right)$ & $2.18 \mathrm{Aab}$ & $1.21 \mathrm{Aa}$ & $0.18 \mathrm{Aa}$ \\
Tied Piece $\left(\mathrm{t} \cdot \mathrm{ha}^{-1}\right)$ & $0.06 \mathrm{Ab}$ & $1.13 \mathrm{Aa}$ & $0.57 \mathrm{Aa}$ \\
Untied Piece $\left(\mathrm{t} \cdot \mathrm{ha}^{-1}\right)$ & $0.93 \mathrm{Ab}$ & $0.96 \mathrm{Aa}$ & $0.55 \mathrm{Aa}$ \\
Splinter $\left(\mathrm{t} \cdot \mathrm{ha}^{-1}\right)$ & $3.4 \mathrm{Aa}$ & $1.82 \mathrm{Aa}$ & $1.71 \mathrm{Aa}$ \\
Shrapnel $\left(\mathrm{t} \cdot \mathrm{ha}^{-1}\right)$ & $1.27 \mathrm{Aab}$ & $0.65 \mathrm{Aa}$ & $0.61 \mathrm{Aa}$ \\
Stump $\left(\mathrm{t} \cdot \mathrm{ha}^{-1}\right)$ & $0.0 \mathrm{Ab}$ & $0.10 \mathrm{Aa}$ & $0.05 \mathrm{Aa}$ \\
Whole Cane $\left(\mathrm{t} \cdot \mathrm{ha} \mathrm{a}^{-1}\right)$ & $4.24 \mathrm{Aa}$ & $1.31 \mathrm{Aa}$ & $2.36 \mathrm{Aa}$ \\
Total Losses $\left(\mathrm{t} \cdot \mathrm{ha} \mathrm{a}^{-1}\right)$ & $12.08 \mathrm{~A}$ & $7.19 \mathrm{~A}$ & $6.02 \mathrm{~A}$ \\
$\%$ of Total Losses & $16.2 \%$ & $9.6 \%$ & $8.1 \%$ \\
\hline
\end{tabular}

Values followed by the same letter (in uppercase) do not differ significantly within the same line. Values followed by the same letter (in lowercase) do not differ significantly within the same column. 
Data from [10] corroborate the findings of [11] who analyzed the effect of increased displacement speed $\left(4.0\right.$ and $\left.5.5 \mathrm{~km} \cdot \mathrm{h}^{-1}\right)$ of the harvester CASE IH A8800 in the state of São Paulo and observed that the increase in speed caused higher losses of raw material.

Likewise [9], analyzing the influence of the increased displacement speed (6.5 and $8.0 \mathrm{~km} \cdot \mathrm{h}^{-1}$ ) in the visible losses of raw materials in the state of São Paulo, using the harvester John Deere 3510, previous model than the evaluated in this study, concluded that there is significant increase in visible losses when using higher displacement speed associated with higher cutting base pressure and the hood of the harvester, especially when analyzing total losses.

The differences between the types of losses within the treatment 1 were significant, with whole cane and splinters found in greater amounts (Table 3). These types of loss amounted $63 \%$ of the total losses (Figure 4). The average total loss was $12.1 \mathrm{t} / \mathrm{ha}$, which means $16.1 \%$ of the total losses in the evaluated speed.

The differences between the types of losses within the treatment 2 were not significant, being numerically splinters the type of loss found in greater amounts (Table 3). This type of loss totals $25.3 \%$ of the total losses (Figure 5). The average total loss was $7.2 \mathrm{t} / \mathrm{ha}$, which means $9.6 \%$ of the total losses in the evaluated speed.

The differences between the types of losses were not significant within the treatment 3 (Table 3), being numerically whole cane found in greater amounts. This type of loss totaled $39.1 \%$ of total losses (Figure 6). The average total loss was $6 \mathrm{t} / \mathrm{ha}$, which means $8.1 \%$ of the total losses in the evaluated speed.

The results found for the splinters and whole cane types of losses in greater amounts are justified, according to [12], the splinter type of loss directly indicates the influence of the rotation of the primary exhaust to the losses. As the

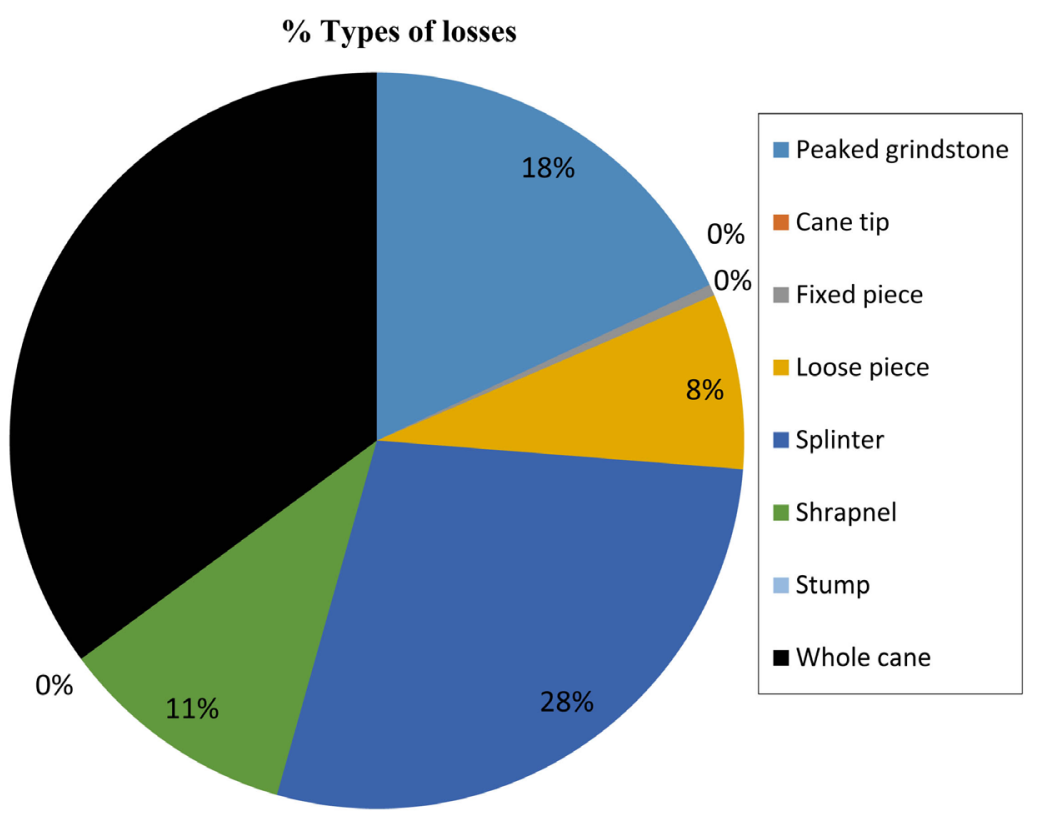

Figure 4. Percentage of the types of losses in treatment 1. 


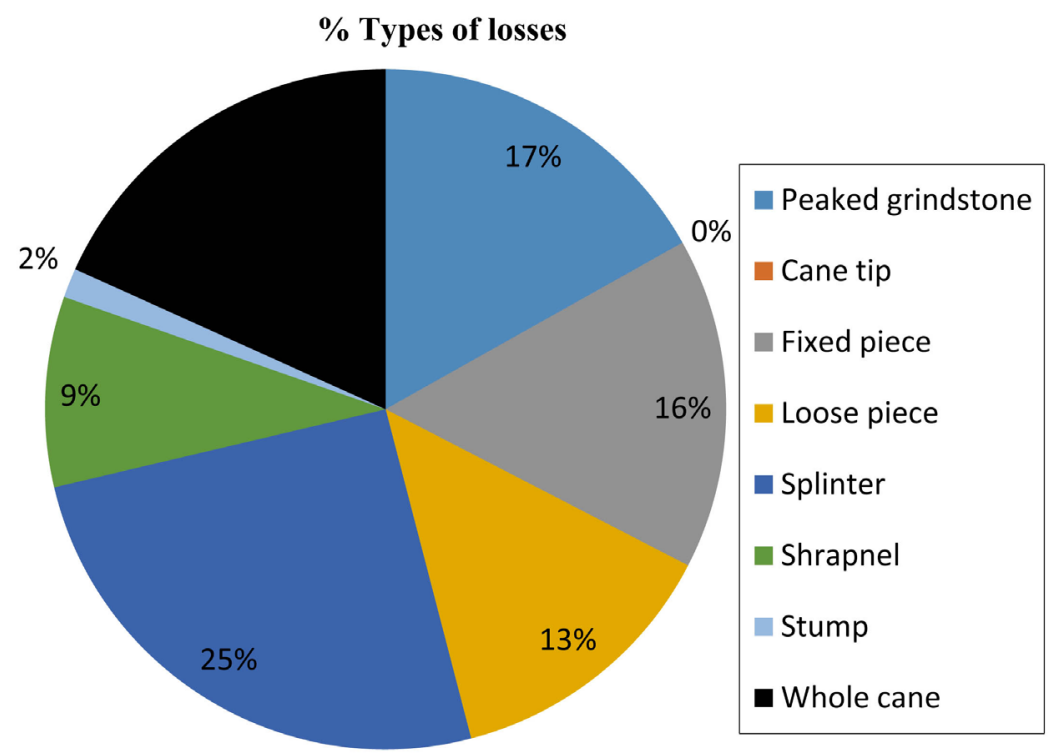

Figure 5. Percentage of the types of losses in treatment 2.

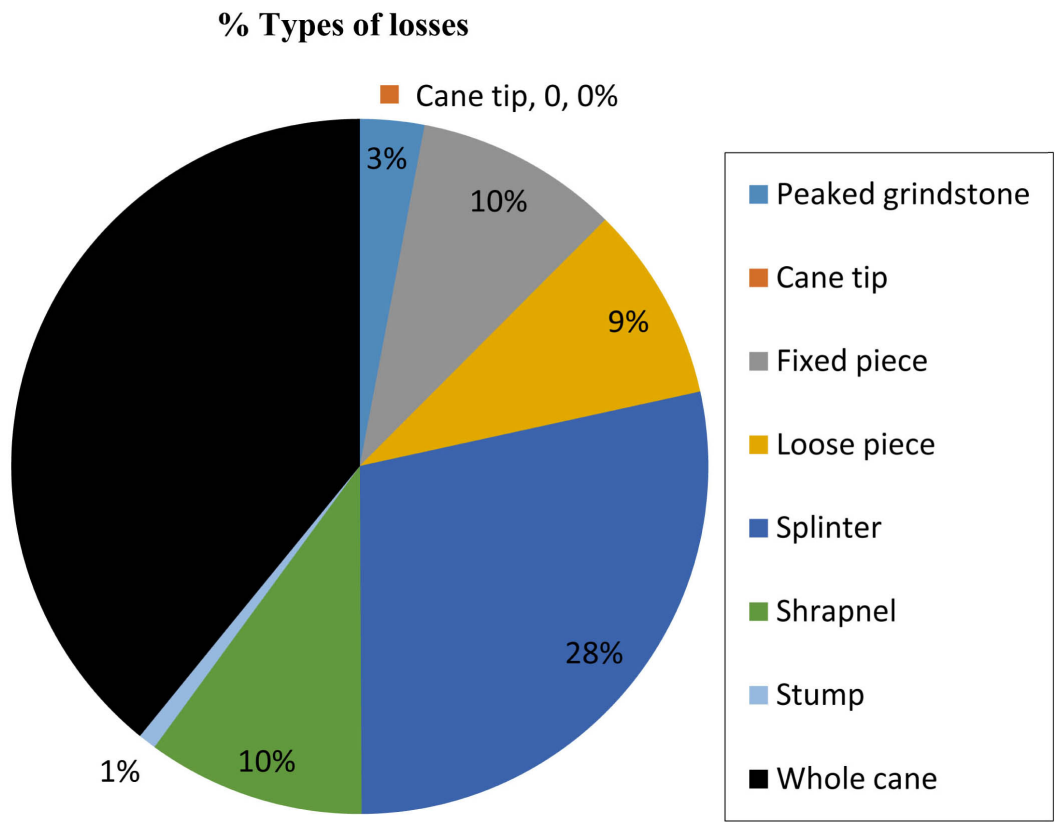

Figure 6. Percentage of the types of losses in treatment 3.

rotation of the primary hood is increased, the grinding are now sucked along with straw and earth, being released the field; when passing through the exhaust, the grinding wheels are hit by the blades, being lacerated into splinters and untied pieces, contributing to increase losses.

The whole cane type of loss found in large quantities in this study is probably related to the lodging of the cane field, because the cane field is not presented uniformly as to its size, with some culms bedridden. According to [13], this lack of uniformity can be lead to increase the losses during harvesting, since it may impair the cutting action in the base of the harvester with the presence of culms 
bedridden. [14] reported that the harvesters operate best in upright, vigorous and deep rooted system canes. Upright canes facilitate cutting, from the base and the top, presenting thereby gains in the ability to work of the machine, because the harvest occurs without major disruptions, leading to lower losses in uncut canes and better cleaning.

This may also be related to the lack of operator training and the lack of efficiency from the harvester crop divider. Other factor would be related to the poor condition of the cutting knives on the base of the harvester, probably they presented wear or damage at the time of harvesting, not allowing the cut of all the stumps, leaving lots of whole cane in the field. Also, another very important factor is related to the unevenness found in the ground, some points in the sampled area had large gaps, lying lots of whole sugar cane in these areas mainly because of high unevenness in the field, the harvester ends up stomping the stumps and lying it on the ground without being able to cut it.

[12] also found splinter types of losses along with untied pieces in greater quantity.

Total losses greater than $4.5 \%$ are classified as high. Following this criterion, losses found in this study in all treatments are rated as high, as it ranged from $8.1 \%$ to $16.2 \%$ (Table 3 ).

Other authors also found in their works total losses classified as high. [9] [13] [15] [16] and [17] found, respectively, in their words, total losses in the order of 4.7\%; $12.5 \% ; 5.0 \%$; $9.3 \%$ and $11 \%$.

Damage sustained in stumps can lead to higher incidence of fungus and disease in it because the fragmentations cause a wound that becomes a gateway to insects and fungi. The damage also influences the ability of regrowth of the stumps. The greater the damage is, the greater will be the probability of pest and disease incidence and less will be the capacity of regrowth of the stumps [6].

By observing Table 4, we can see that the statistical differences between the speeds were not significant. Thus, suggesting that using the higher speed would be indicated to prevent further damage to the stumps under the field conditions of this study.

On the other hand [6], while evaluating the damage to stumps at three different displacement speeds $\left(2.0,3.0\right.$ and $\left.4.5 \mathrm{~km} \cdot \mathrm{h}^{-1}\right)$ of the harvester CASE IH A8800, found a significant difference between the speeds only for level 1 (without damage), being found more damage of level 1 at the highest speed used,

Table 4. Comparison of the stump damage levels between different speeds.

\begin{tabular}{cccc}
\hline Damage level & $\begin{array}{c}\text { Speed: } \\
3 \mathrm{~km} \cdot \mathrm{h}^{-1}\end{array}$ & $\begin{array}{c}\text { Speed: } \\
4 \mathrm{~km} \cdot \mathrm{h}^{-1}\end{array}$ & $\begin{array}{c}\text { Speed: } \\
5 \mathrm{~km} \cdot \mathrm{h}^{-1}\end{array}$ \\
\hline 1-Without damage & $22 \mathrm{~A}$ & $15 \mathrm{~A}$ & $16 \mathrm{~A}$ \\
2-Peripheral damage & $14 \mathrm{~A}$ & $21 \mathrm{~A}$ & $20 \mathrm{~A}$ \\
3 -Crack & $12 \mathrm{~A}$ & $7 \mathrm{~A}$ & $8 \mathrm{~A}$ \\
$4-$ Fragmented & $2 \mathrm{~A}$ & $7 \mathrm{~A}$ & $6 \mathrm{~A}$ \\
\hline
\end{tabular}

Values followed by the same letter do not differ significantly within the same line (Tukey, 5\%). 
concluding that the use of the higher speed $\left(4.5 \mathrm{~km} \cdot \mathrm{h}^{-1}\right)$ would be more appropriate because it causes less damage to stumps.

In treatment 1 , level 1 was found in greater numbers, totaling $44 \%$ of the evaluated stumps, followed by grade 2, grade 3 and grade 4 (Table 4). This means that the type of damage found in greater amounts in the lower speed used was the "without damage", and the "fragmented" was the level found in lesser amounts in only $4 \%$ of the stumps (Figure 7).

In treatment 2 , level 2 was found in greater numbers, totaling $42 \%$ of the evaluated stumps, followed by grade 1, grade 3 and grade 4 (Table 4, Figure 8). This means that the type of damage found in the largest amount was the peripheral damage and damages classified as cracks, and fragmented was the level found in smaller quantities, these two totaling $28 \%$ of the stumps.

In treatment 3 , level 2 was found in greater numbers, totaling $40 \%$ of the evaluated stumps, followed by grade 1, grade 3 and grade 4 (Table 4, Figure 9). This means that the type of damage found in the largest amounts was the peripheral damage, and damages classified as fragmented were found in lesser amounts, totaling $12 \%$ of the stumps.

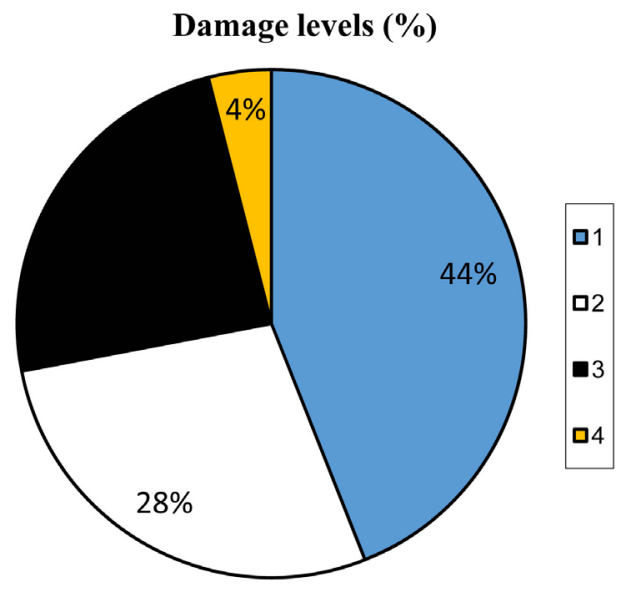

Figure 7. Percentages of damage levels in the treatment 1.

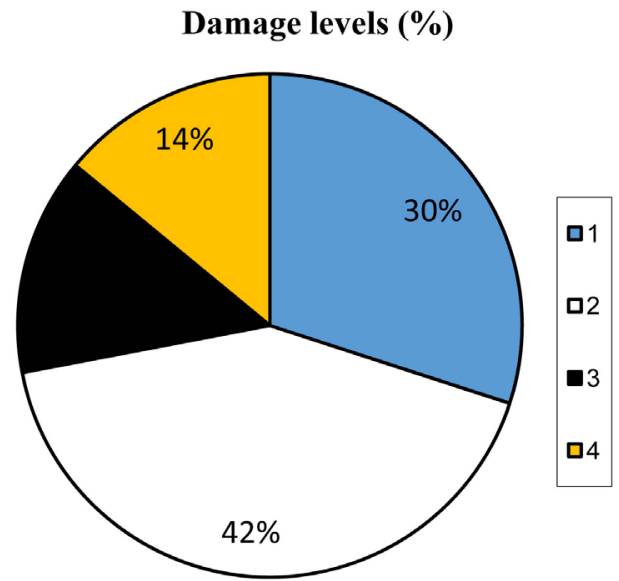

Figure 8. Percentages of damage levels in the treatment 2. 


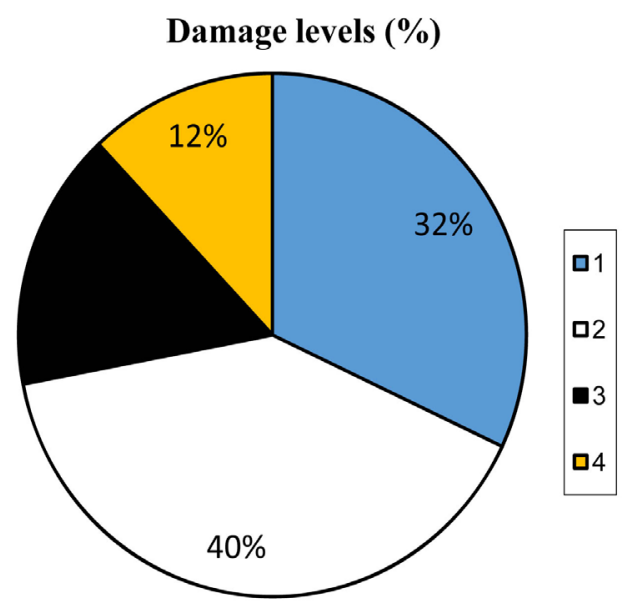

Figure 9. Percentages of damage levels in the treatment 3.

\section{Conclusions}

- In the conditions under which this experiment was conducted, the displacement speed of the harvester did not influence significantly the visible crop losses nor in the stump damage.

- Thus, it is elucidated that regardless of the displacement speed applied in the harvester John Deere 3520, significant loss differences will not occur. This way, it is more advantageous to apply in the harvester the speed of $5 \mathrm{~km} \cdot \mathrm{h}^{-1}$, harvesting more in less time as compared to the other speeds studied.

\section{Acknowledgements}

- To CNPq, for the concession of a doctorate scholarship to the first author.

- To FAPERJ, for the financial support and for the execution of the research study.

- The Paraíso plant by indulging the area of sugarcane for study.

\section{Conflicts of Interest}

The authors declare no conflicts of interest regarding the publication of this paper.

\section{References}

[1] Reis, G.N., Calafange, A., Barreto, A.K.G., Silva, R.P. and Toledo, A. (2010) Whichislost. Vol. 10, Cultivar Máquinas, Pelotas, 34-36.

[2] Ripoli, T.C.C. and Ripoli, M.L.C. (2009) Sugarcane Biomass: Harvesting, Energy and Environment. CollegeofAgriculture "Luiz de Queiroz", Piracicaba, 333.

[3] Reis, G.N. (2009) Losses in the Mechanized Harvest of Raw Sugar-Cane Due to Wear on Cutting Base Blades. Doctoral Degree's Thesis, Faculty of Agriculturaland Veterinary Sciences-UNESP, Jaboticabal.

[4] Kroes, S. (1997) The Cutting of Sugarcane. Doctoral Degree's Thesis, University of Southern Queensland, Toowoomba.

[5] Garcia, R.F. and Silva, L.S. (2010) Evaluation of Manual and Mechanical Sugar Cane 
Harvesting Performance in Campos dos Goytacazes, RJ. Engenharia na Agricultura, Viçosa, 234-240.

[6] Manhães, C.M.C., Garcia, R.F., Correa Júnior, D., Francelino, F.M.A., Francelino, H.O. and Santos, C.M.F.G. (2014) Evaluation of Visible Losses and Damage to the Ratoon Cane in the Mechanized Harvesting of Sugarcane for Different Displacement Speeds. American Journal of Plant Sciences, 5, 2956-2964. https://doi.org/10.4236/ajps.2014.520312

[7] Ripoli, T.C.C., Nery, M.S., León, M.J. and Piedade, S.M.S. (1999) Operating Performance of a Harvester on Raw Sugar on the Basis of Forward Speed. The Engenharia Agrícola Journal, 19, 199-207.

[8] Carvalho, L.S. (2009) Operational Performance of a Harvester in Greencane in Thearea of Grande Dourados-MS. Masters Degree's Dissertation, Universidade Federal da Grande Dourados, Dourados.

[9] Segato, S.V. and Daher, F. (2011) Visiblelosses in Mechanical Harvesting of Sugarcane Raw in Travel Speeds of the Harvester. Nucleus, 8, 315-326.

https://doi.org/10.3738/1982.2278.471

[10] Silva, R.C., Oliveira, T.C., Figueiredo, Z.N. and Caldeira, D.S.A. (2015) Visible Losses in the Mechanical Harvest of Sugarcane. Engenharia na Agricultura, Viçosa, 71-77.

[11] Ramos, C.R.G., Lanças, K.P., Lyra, G.A. and Millani, T.M. (2014) Qualityof Sugar Cane Mechanized Harvest as Function of the Forward Speed and Engine Rotation of the Harvester. Energia na Agricultura, Botucatu, 87-94.

[12] Neves, J.L.M., Magalhães, P.S.G. and Ota, W.M. (2004) Sugar Cane Loss Monitor, Adapted to a Commercial Chopper Sugar Cane Harvester. Engenharia Agrícola, 24, 764-770. https://doi.org/10.1590/S0100-69162004000300030

[13] Silva, R.P., Corrêa, C.F., Cortez, J.W. and Furlani, C.E.A. (2008) Statistical Control Applied in the Process of Mechanical Sugar Cane Harvest. Engenharia Agrícola, 28, 292-304. https://doi.org/10.1590/S0100-69162008000200010

[14] Silva, F.I.C. and Garcia, A. (2009) Harvest Mechanics and Manual of the Cana-De Açúcar: Description and Analysis. Nucleus, 6, 233-247.

[15] Schogor, A.L.B., Nussio, L.G., Mourão, G.B., Muraro, J.O.S. and Matos, B.C. (2009) Losses in Sugarcane Submitted to Different Harvesting Methods. Revista Brasileira de Zootecnia, 38, 1443-1450. https://doi.org/10.1590/S1516-35982009000800007

[16] Noronha, R.H.F., Silva, R.P., Chioderoli, C.A., Santos, E.P. and Cássia, M.T. (2011) Statistical Control Applied in the Process of Mechanical Sugar Cane Harvest in the Diurnal and Nocturnal Periods. Bragantia, 70, 931-938. https://doi.org/10.1590/S0006-87052011000400028

[17] Manhães, C.M.C., Garcia, R.F., Correa Júnior, D., Francelino, F.M.A., Vasconcelos Júnior, J.F.S. and Francelino, H.O. (2013) Quantitative Losses and Rao on Damage during Sugar Cane Harvesting in the North Fluminense. Vol. 15, Vértices, Campos dos Goytacazes, 63-74. 